\title{
The Northern Limit of Trees in Labrador: A Discussion
}

\author{
DEBORAH L. ELLIOTT ${ }^{1}$ and SUSAN K. SHORT ${ }^{1}$
}

\begin{abstract}
We have found that the northernmost trees in Labrador occur at Napaktok Bay on the Labrador coast, as suggested by early explorers, rather than along either Nakvak Brook, Saglek Fiord, or the Hebron Fiord area as suggested by most modern workers.
\end{abstract}

\section{INTRODUCTION}

Considerable confusion exists in the literature concerning the northern limit of trees in Labrador. Early explorers of northern Labrador (Coleman, 1921; Wheeler, 1935, 1936; Tanner, 1944) stated that the northernmost trees were to be found at the inner end of Napaktok (Black Duck) Bay $\left(57^{\circ} 55^{\prime} \mathrm{N}\right.$., $62^{\circ} 40^{\prime}$ W.). More recent maps and texts have indicated trees further north at: 1) Hebron Fiord and the small valley to the north (Wenner, 1947; Hare, 1959; Canada, Dept. Energy, Mines and Resources, 1967, 1968; Rowe, 1972); 2) Saglek Fiord (Hare, 1959; Rowe, 1972); and 3) Nakvak Brook (Canada, Dept. Energy, Mines and Resources, 1967; Tuck, 1975) (Fig. 1). Mapping of many of these 'northernmost trees' has been done through air photo interpretation without adequate field checking. We are defining a 'tree' here as a woody plant with a single main stem at least $2 \mathrm{~m}$ in height.

The above phytogeographical conflict led to our searching for the true limit of trees in Labrador as part of the Institute of Arctic and Alpine Research's continuing paleoclimatic and ecological studies of northern Canada. This field checking was conducted in the summers of 1975 by Short (Ives, Nichols and Short, 1976; Short, 1978) and in 1978 by Elliott. We were accompanied by Drs. H. Nichols and J. D. Ives in 1975 and Nichols and K. J. Hansen in 1978.

\section{OBSERVATIONS FROM REPORTED NORTHERN TREE SITES}

The northernmost reported tree site in Labrador is along Nakvak (Nakhvararsuk) Brook, at the southeast end of the Torngat Mountains. Wheeler (1935) states that there were early reports of trees in this area, yet in his own explorations, he found only willow to exist here. Observations from aircraft in 1975 and 1978 did not show any trees in the area, only limited shrub cover.

In 1957 J. D. Ives and P. C. Ives discovered a small clone of spruce (probably Picea mariana (Mill.) B.S.P.), less than $2 \mathrm{~m}$ in height, on the col between the Koroc River, Quebec, and Nakvak Brook, Labrador (58 $37^{\prime} \mathrm{N}$,

Institute of Arctic and Alpine Research and Departments of Geography' and Anthropology', University of Colorado, Boulder, Colorado 80309 USA 


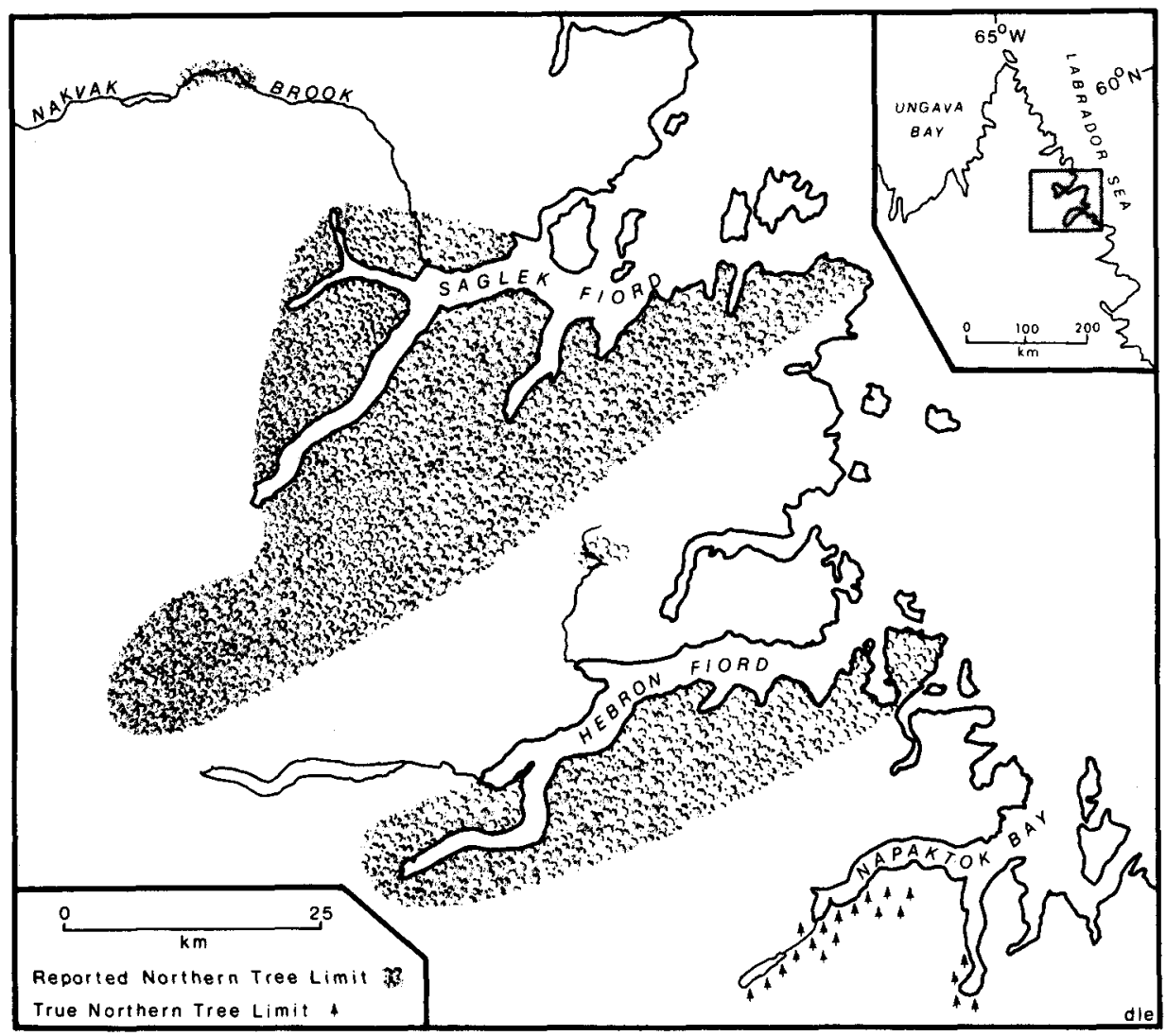

FIG. 1. Map of the northern tree limit in Labrador, Canada. The correct arctic tree limit is shown at Napaktok Bay, with formerly reported northern tree locations (now disproven by our field checking) shown as shrublands.

$64^{\circ} 7^{\prime} 30^{\prime \prime} \mathrm{W}$ ) in the Torngat Mountains (pers. comm., 1978). These plants were at an elevation of about $305 \mathrm{~m}$, considerably above the limit of trees in the Koroc drainage. Because no cones were seen, it was assumed that the spruce were reproducing by layering. It is our opinion that these spruce entered the col from the Koroc drainage and therefore do not reflect the topographic problem of migrating along the Labrador coast nor the controls of the tree limit in Labrador.

Recent vegetation maps of Labrador-Ungava show trees existing in the Saglek Fiord area. Rowe (1972) shows this area as 'forest and barren', whereas Hare (1959) uses the terminology 'forest tundra'. Aerial reconnaissance in 1975 did not reveal any trees, and shrub cover is limited to the more mesic valley locations.

H. Lamb (pers. comm., 1978) reports that there is a small clone of Populus tremuloides Michx. (quaking aspen) on a scree face at Saglek Fiord. We have not confirmed this report, nor do we know if the species assumes a tree-form there. The northern limit of quaking aspen on the Labrador coast is reported 
as the Hamilton River/Hamilton Inlet complex by Marie-Victorin (1964) and confirmed by Short.

Canadian topographical maps (Canada, Dept. Energy, Mines and Resources, 1967, 1968) show forest along the first valley $\left(58^{\circ} 12^{\prime} \mathrm{N}, 63^{\circ} 02^{\prime} \mathrm{W}\right)$ north of Hebron Fiord. Several hours of hiking in the area revealed no coniferous trees, but. instead a dense shrubland of alder (Alnus crispa (Ait.) Pursh), various willow (Salix L.) species, and birch (Betula glandulosa Michx.) was observed (Fig. 2).

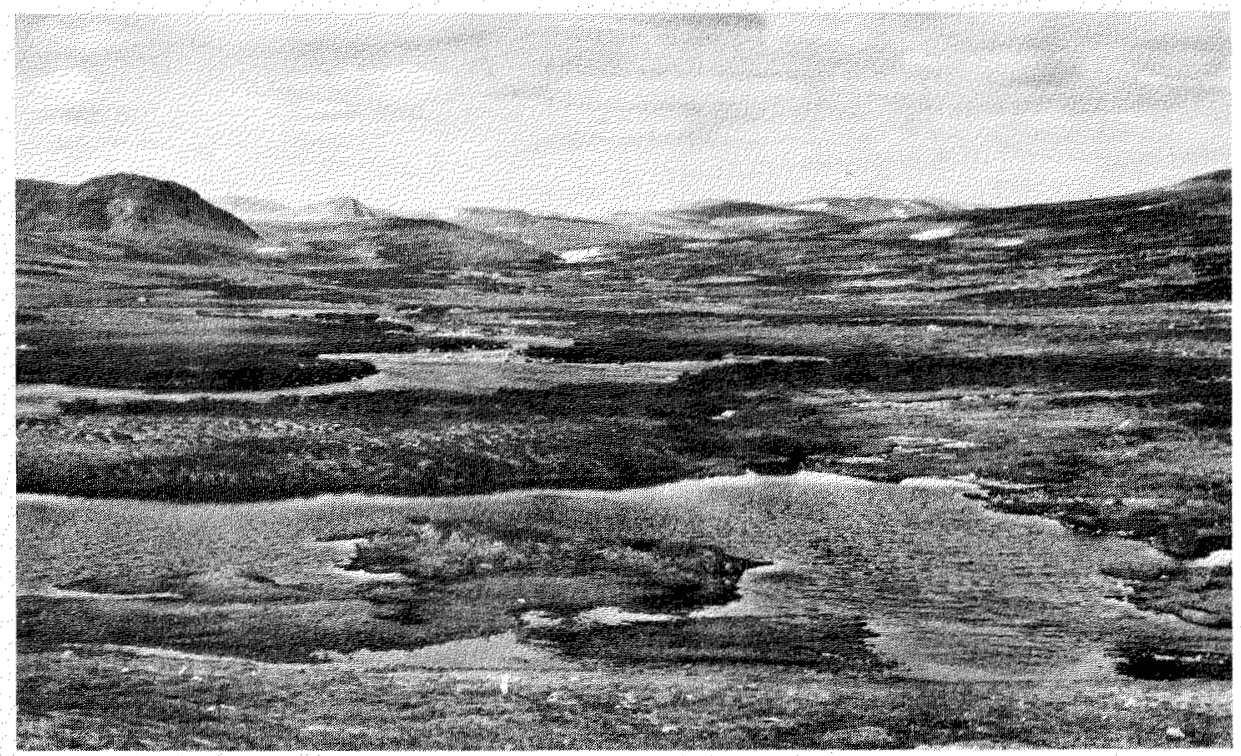

FIG. 2. Valley north of Hebron Fiord where trees had been mapped. Vegetation of area is an alder-birch-willow shrubland. The dense thickets contain shrubs approaching $2 \mathrm{~m}$ in height and $10-15 \mathrm{~cm}$ in diameter.

H. Lamb (pers. comm., 1978) visited the same area in 1977, looking for spruce depicted on the Canadian topographical maps. His observations were made from the air and the lake as he did not go ashore. Lamb reports that the " "trees', "were "not quite possible to make out — might have been stunted spruces but no bleached white old trees that I could see; plenty of alder and dwarf birch". Lamb is correct in expecting, if spruce were present, to see dead, white tree trunks, which are highly visible at Napaktok Bay and on the Kogaluk River Plateau. What he was seeing, from our field checking in this area, was Salix planifolia Pursh., a shrub willow which reaches heights approaching $2 \mathrm{~m}$.

In 1978, the north wall of Hebron Fiord, where trees had been reported, was briefly searched by air. Once again, no trees were found, only an alder-willow-birch shrubland.

There is a herbarium specimen (no. 1034) of white spruce (Picea glauca (Moench) Voss) from Hebron in the Museum of Natural Sciences, Canada, 
which was collected on 21 July 1936 by Dr. N. Polunin (Gillett, pers. comm., 1978). This specimen has no cones and abnormally short needles. We attempted to confirm the collection site for this specimen with Dr. Polunin. Since he could not locate his 1936 field notes, he could not say positively that this site was Hebron, nor whether the spruce were on the valley wall or in the small valley to the north of the fiord proper. He states, "I encountered a few scattered dwarf spuce (whether black or white I do not recall but I am pretty sure there were no Larix) not far inland at one of the most northern settlements, not more than a few kilometres inland at most". He thinks the place of the 'little spruce' was Hebron though he cannot "be sure enough to let such a mere recollection stand as a record". In any case, he says "they were mere dwarfs which could scarcely have exceeded a metre in height or been visible from the air" (Polunin, pers. comm., 1978).

Dr. J. M. Gillett (pers. comm., 1978), curator of vascular plants at the same museum, states that he was in the Hebron area in 1954 and did not see white spruce.

In summary, white spruce in a dwarf, shrub-form might at one time have existed somewhere in the Hebron area. This species has not been reported by other botanists working in this area since 1936. Therefore, the species may have been exterminated (either by the natives or a minor climatic cooling) or may be so local in extent that it has not been rediscovered. The finding of

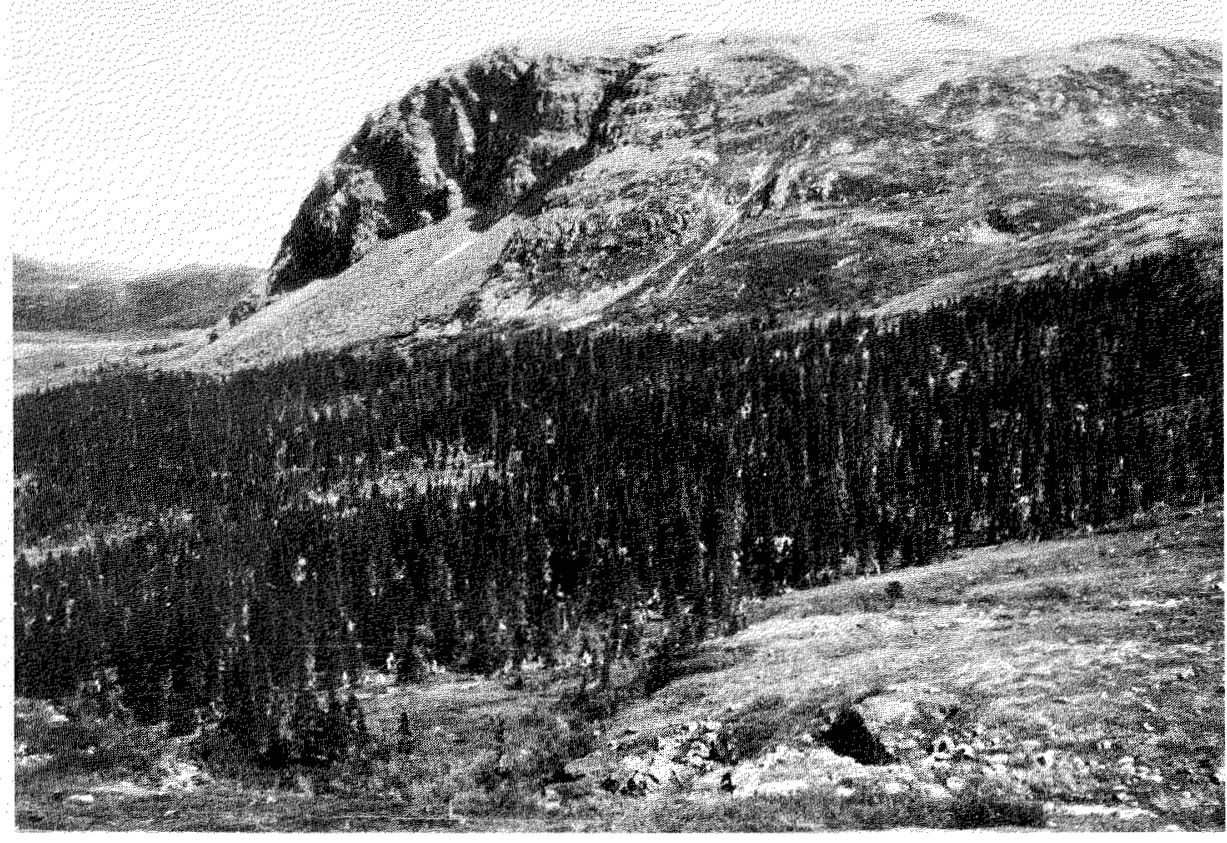

FIG. 3. Northern Labrador tree limit at Napaktok (Black Duck) Bay. The forest here is composed of large, upright white spruce (Picea glauca). The trees are very healthy, and many different ages are present in the stand. 
Polunin's original field notes from 1936 would be of great assistance, but in any case we plan on revisiting the Hebron area to do more intensive searching in the summer of 1979.

We propose the next bay south, Napaktok (Black Duck) Bay, as the true northern tree limit. On the glacio-fluvial terraces and lower slopes of the southern part of the bay, dense forests of white spruce were found (Fig. 3). Scattered dwarf white spruce were found up-valley and along the higher lake shores forming a stressed altitudinal tree line at ca. $140 \mathrm{~m}$.

The forest here, like the shrubland at Hebron, appeared very old and contained many fallen trees. Reproduction is taking place, with a wide variety of age classes of trees present. This forest appears to be in equilibrium with the present climate, in contrast to the northern trees of Keewatin (Elliott, 1979).

The uppermost, stunted white spruce however, were not producing cones. No seedlings were seen in these areas. Saplings were estimated to be about 100 years old, on the basis of our previous dendroecological experience; the ages are being checked.

Black spruce and balsam fir (Abies balsamea (L.) Mill.) are listed by Gardner (1973) as existing in the Napaktok Bay forest. These were not seen, but may be found subsequently when the entire area is explored on foot. They were not seen through aerial reconnaissance, as might be expected due to the different foliage colours of the species.

\section{SUMMARY}

The northern tree limit on the Labrador coast is at Napaktok Bay. This limit is formed by a true forest, in contrast to either the open lichen woodlands or the scattered dwarf spruce in the forest-tundra ecotone which form the tree limit in western Canada. The better our understanding of the modern geographic limits, and the environmental factors controlling the limits, of plant communities and individual taxa in the Canadian arctic and subarctic, the more accurate will be our interpretation of the dendroecological and palynological data relevant to the Holocene migration of the northern Canadian tree limit.

\section{ACKNOWLEDGEMENTS}

This is a contribution to U.S. National Science Foundation grants DEB78-07560 and ATM77-17549. The research was also supported by grants-in-aid of research from the Arctic Institute of North America, the Explorers Club, Sigma Xi, the Graduate School of the University of Colorado, and the Smithsonian Institution.

We would like to thank K. J. Hansen for her assistance in the field in 1978, Drs. H. Nichols and J. D. Ives for their supervision in Labrador, encouragement of our studies, and comments on the manuscript, and Drs. J. T. Andrews, R. G. Barry, J. A. Larsen, P. J. Webber, Y. A. Linhart, H. A. Fritts, W. W. Fitzhugh, and R. Stuckenrath for their discussions and support of our work in Labrador-Ungava. 


\section{REFERENCES}

CANADA, DEPT. ENERGY, MINES and RESOURCES. 1967. Topographical map 14L (Hebron). Mapping and Charting Establishment, Dept. National Defence.

1968. Topographical maps $14 \mathrm{E} / 15$ and $14 \mathrm{~L} / 3$. Mapping and Charting Establishment, Dept. National Defence.

Coleman, A. P. 1921. Northeastern part of Labrador, and New Quebec. Canada, Geological Survey Memoir 124.

ELLIOTT. D. L. 1979. The current regenerative capacity of the northern Canadian trees, Keewatin, N.W.T.: some preliminary observations. Arct. Alp. Res. 11(2): (in press).

GARDNER, G. 1973. Analytic catalogue of plant species from the arctic and subarctic of Quebec and other regions of Canada. University of Montreal, Canada. $236 \mathrm{pp}$.

GILLETT, J. M. 1978. Personal communication (Museum of Natural Sciences, Ottawa, Canada).

HARE, F. K. 1959. A photo-reconnaissance survey of Labrador-Ungava. Canada, Geographical Branch, Mines and Technical Surveys Memoir 6. $83 \mathrm{pp}$.

IVES, J. D. and IVES, P. C. 1978. Personal communication (University of Colorado, Boulder, Colorado, U.S.A.).

-.. NICHOLS, H. and SHORT, S. 1976. Glacial history and paleoecology of northeastern Nouveau-Quebec and northern Labrador. Arctic, 29: 48-52.

LAMB, H. 1978. Personal communication (Botany School, Cambridge University, Cambridge, U.K.).

MARIE-VICTORIN, FRERE. 1964. Flore Laurentienne. Les Presses de l'Universite de Montreal, Montreal. $925 \mathrm{pp}$.

POLUNIN, N. 1978. Personal communication (Geneva, Switzerland).

ROWE, J. S. 1972. Forest regions of Canada. Canada, Dept. of the Environment, Canadian Forestry Service Publication no. 1300.172 pp.

SHORT, S. K. 1978. Holocene palynology in Labrador-Ungava: Climatic history and culture change on the central coast. Unpublished Ph.D. thesis, University of Colorado.

TANNER, v. 1944. Outlines of the geography, life, and customs of Newfoundland-Labrador. Acta Geographica, 8: 1-907.

TUCK, J. A. 1975. Prehistory of Saglek Bay, Labrador: Archaic and palaeo-eskimo occupations. Canada, National Museum of Man Mercury Series, Archaeological Survey of Canada Paper no. 32, $272 \mathrm{pp}$.

WENNER, C. G. 1947. Pollen diagrams from Labrador. Geografiska Annaler, 29: 137-373.

WHEELER, E. P. 1935. The Nain-Okak section of Labrador. Geographical Review 25: 240-254. 475-481. 